\title{
Use of Crushed Seashell by-Products for Sandy Subgrade Stabilization for Pavement Purpose
}

\author{
Gaby Ruiz, Mgtr ${ }^{1}$ and Pierre Farfán, Eng ${ }^{2}$ \\ ${ }^{I}$ University of Piura, Peru, gaby.ruiz@udep.pe \\ ${ }^{2}$ Professional Engineer, Peru, pierre.farfan.raymundo@gmail.com
}

\begin{abstract}
This research aims to explore an alternative utilization of seashell wastes in sandy subgrade stabilization in order to reduce environmental pollution. Crushed Peruvian Scallop was mixed with silty sand subgrade through mechanical stabilization at $20 \%$, $40 \%$, 60\%, and $80 \%$ soil subgrade replacement. Seashells were simply washed and sun-dried before being crushed. Evaluation of the crushed seashell (CSS) reveals that it can be considered as a gravel material, with flat but not elongated particles of $25 \%$ of Los Angeles Abrasion loss value. Laboratory testing and analysis determined that it meets the American Association of State Highway and Transportation Officials' (AASHTO) requirements for use as a subbase and base coarse material at $45 \%$ replacement of fine soil aggregate. The CSS addition in sandy soil increases the maximum density using less water than the control group, with the same compaction energy. The CSS addition also increases the California Bearing Ratio (CBR) of sandy soil from $51 \%$ to more than $100 \%$. It can be concluded that crushed waste Peruvian Scallop has the potential to perform as a mechanical soil stabilizer, or for soil modification for pavement applications, simply using washing and sun-drying treatment.

Keywords-Subgrade stabilization, seashell, pavement, CBR.
\end{abstract}

Digital Object Identifier (DOI):

http://dx.doi.org/10.18687/LACCEI2016.1.1.053

ISBN: 978-0-9822896-9-3

ISSN: 2414-6390

$14^{\text {th }}$ LACCEI International Multi-Conference for Engineering, Education, and Technology: "Engineering Innovations for Global Sustainability", 20-22 July 2016, San José, Costa Rica. 


\title{
Use of Crushed Seashell by-Products for Sandy Subgrade Stabilization for Pavement Purpose
}

\author{
Gaby Ruiz, Mgtr ${ }^{1}$ and Pierre Farfán, Eng. ${ }^{2}$ \\ ${ }^{1}$ University of Piura, Peru, gaby.ruiz@udep.pe \\ ${ }^{2}$ Professional Engineer, Peru, pierre.farfan.raymundo@gmail.com
}

\begin{abstract}
This research aims to explore an alternative utilization of seashell wastes in sandy subgrade stabilization in order to reduce environmental pollution. Crushed Peruvian Scallop was mixed with silty sand subgrade through mechanical stabilization at $20 \%, 40 \%, 60 \%$, and $80 \%$ soil subgrade replacement. Seashells were simply washed and sun-dried before being crushed. Evaluation of the crushed seashell (CSS) reveals that it can be considered as a gravel material, with flat but not elongated particles of 25\% of Los Angeles Abrasion loss value. Laboratory testing and analysis determined that it meets the American Association of State Highway and Transportation Officials' (AASHTO) requirements for use as a subbase and base coarse material at $45 \%$ replacement of fine soil aggregate. The CSS addition in sandy soil increases the maximum density using less water than the control group, with the same compaction energy. The CSS addition also increases the California Bearing Ratio (CBR) of sandy soil from 51\% to more than 100\%. It can be concluded that crushed waste Peruvian Scallop has the potential to perform as a mechanical soil stabilizer, or for soil modification for pavement applications, simply using washing and sun-drying treatment.
\end{abstract}

Keywords-Subgrade stabilization, seashell, pavement, CBR.

\section{INTRODUCTION}

The use of shellfish is an expanding economic activity worldwide [1]. The residues that result lead to environmental pollution as a result of unpleasant odor, insects and fungi on open-dump sites [2-9].

More effort is needed to find use for these wastes in such a way as to reduce environmental problems $[1,9]$. Using wastes materials in civil engineering offers a low energy consumption alternative to recycling [9-10].

Some research has been done on the use of waste seashells materials in civil engineering: periwinkles, crushed scallop and crepidula shells have been as aggregate replacements in concrete [2-8, 11-17]; in a powder condition as cementitious materials $[18,19,20]$ or as filler in hot mixes [21]. The general findings reveal that seashells can be used as an aggregate replacement, but the salt content and chloride ion presence in seashells can be harmful to concrete or asphalt mixes. Some others researchers have explored its uses in pavement subgrade stabilization of clayed or compressive soils [22-25]. The results show that crushed shell can be effectively utilized as a subgrade improvement, reducing plasticity and increasing the bearing capacity. Typically, for subgrade stabilization, lime is used in cohesive clay-type soils, while cement or fly ash is used in non-cohesive sandy-type soils. The amount of cement mixed with the soil is usually $3 \%$ to $10 \%$ by dry weight of the soil, with higher percentages for

Digital Object Identifier (DOI): http://dx.doi.org/10.18687/LACCEI2016.1.1.053 ISBN: 978-0-9822896-9-3

ISSN: $2414-6390$ finer materials having a greater surface area [38]. But no technical information on the use of crushed waste scallop for pavement base applications was found.

In this research, Peruvian Scallop is used for the stabilization of sandy subgrade in pavement application. In Peru, Peruvian Scallop (Argopecten purpuratus) is one of the most important species to be grown, and it is actually exported to China, the United Kingdom, Canada, Iceland, Australia and Chile [26]. In Sechura, Northern Peru, more than $80 \%$ of national production is managed, and up to 25000 metric tons (TM) of empty hard seashell is discarded annually as waste in municipal landfills [27]. New Peruvian government environmental standards have been applied to processing plants which require waste management alternatives [28].

This research aims to explore the effect of the addition of crushed seashell to sandy subgrades through mechanical stabilization for pavement applications.

\section{METHODOLOGY}

\section{A. Experimental material}

1) Subgrade material: Natural rounded silty fine sand with some calcareous stone from Sechura, Peru was used as subgrade material. This sand is a coastal stratum formed by sedimentation throughout alluvial and air transportation. The main selection criterion was location in an urban area at a limited distance from seashell landfills.

2) Seashell waste: Seashell waste was recovered from municipal landfill located in Sechura. The Peruvian Scallop is a bivalve mollusk with two symmetrical hard shell sections joined at one end by a hinged ligament. The shells are essentially calcareous material [29] in flat and curved shaped of almost 2 to $3 \mathrm{~mm}$ thickness. One of the shells is more concave than the other. The interior of the shells is smooth, and the exterior porous, and is ribbed in a radial orientation. Before crushing, the size of the samples used in this research ranged from $8.0 \mathrm{~cm}$. to $12 \mathrm{~cm}$. Fig. 1 shows some samples of Peruvian scallops identified in this research.

\section{B. Crushed seashell preparation}

Empty seashells collected from landfill were washed to remove dirt and any organic matter using water. They were then sun-dried. No other washing method or materials were used for cleaning purposes. Although salt content is not harmful to soil stabilization, the washing process was used to eliminate its effect on compaction. Seashells were crushed and sieved using 2" and No. 20 ASTM sieves.

C. Mixture proportions

Four mixes were prepared. Soil was replaced with crushed seashell (CSS) in weight $(20 \%, 40 \%, 60 \%$, and $80 \%)$

$14^{\text {th }}$ LACCEI International Multi-Conference for Engineering, Education, and Technology: "Engineering Innovations for 1 Global Sustainability", 20-22 July 2016, San José, Costa Rica. 
and compared against the control group (0\%) without seashells.

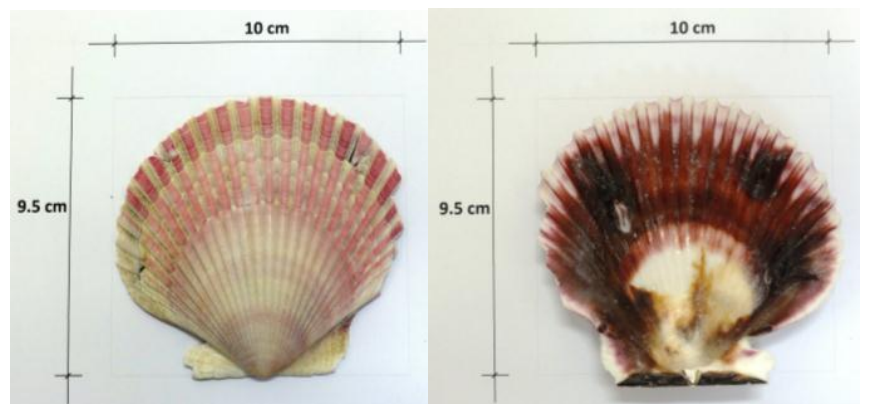

Fig. 1 Sample of Peruvian scallop shell used in the present research. The exterior and interior sides of the shells can be observed.

\section{Testing methods}

Grain-size distribution [30], Liquid Limit, Plastic Limit, and Plasticity Index [31], and Los Angeles abrasion [32-33] tests were applied to natural sand and also to the CSS materials. In addition, flat and elongated particles [34] in CSS were evaluated in terms of them being a coarse aggregate. California Bearing Ratio (CBR) and moisture-density relations using modified the Proctor compaction test were used, according to ASTM and AASHTO specifications for road applications [35-36] to evaluate the CSS addition effect on natural soil.

\section{RESULTS AND DISCUSSION}

\section{A. Engineering properties of natural soil and crushed} seashell

During crushed seashell preparation, no jaw or mill crushing machines from the laboratory were of use for crushing. A great deal of hand effort using a manual grinder was used (Fig. 2). This indicates a need to break the shell by impact or rolling, as the curved shape can be appropriate for crushing. On site, a rolling machine involving rolling over shells placed on the soil can be a good way to carry out the crushing and mixed process in the same step.

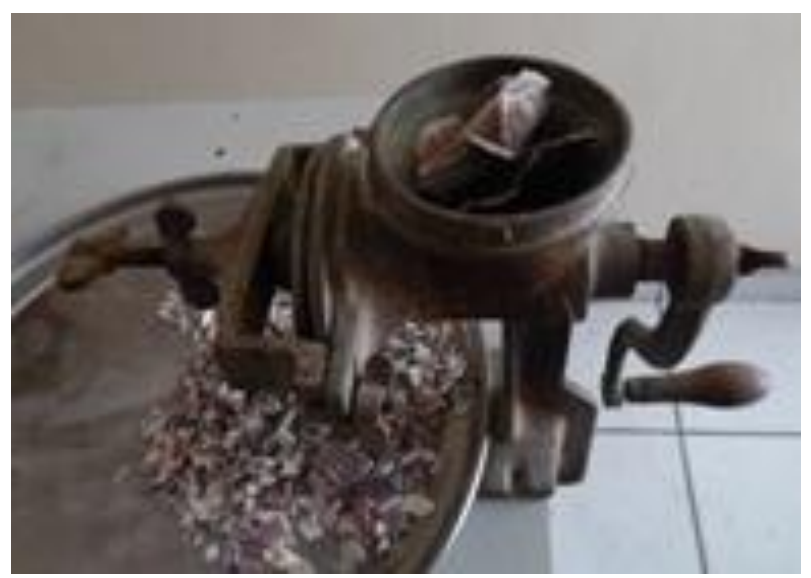

Fig. 2 Manual grinder used to facilitate crushing of seashells.

Table I presents the soil properties of both subgrade soil and CSS material. Neither natural soil nor CSS has plasticity. Some plasticity can be helpful in compaction in terms of reducing the mechanical effort needed to get better density. In natural conditions, a subgrade has a water content of $7.8 \%$ in mass, which can be useful for compaction purposes.

TABLE I

PROPERTIES OF NATURAL SOIL AND CRUSHED SEASHELL EVALUATED IN THE LABORATORY

\begin{tabular}{|c|c|c|}
\hline Parameter & Natural soil & Crushed seashell \\
\hline Liquid Limit (\%) & --- & --- \\
\hline Plastic Limit (\%) & --- & --- \\
\hline Plasticity Index (\%) & $\mathrm{NP}^{\mathrm{a}}$ & $\mathrm{NP}^{\mathrm{a}}$ \\
\hline Natural water content (\% mass) & 7.8 & 0.3 \\
\hline Specific Gravity (Gs) ${ }^{b}$ & 2.58 & 2.50 \\
\hline Percentage $<0.074 \mathrm{~mm}$ & 17.0 & 0.0 \\
\hline USCS $^{\mathrm{C}}$ Classification & $\mathrm{SM}^{\mathrm{d}}$ & $\mathrm{GP}^{\mathrm{e}}$ \\
\hline AASHTO $^{f}$ Classification & A-2-4 (0) & A-1-a (0) \\
\hline
\end{tabular}

${ }^{\mathrm{a} N o n}$ plastic.

${ }^{\mathrm{b}} \mathrm{A}$ dimensional parameter.

${ }^{c}$ Unified Soil Classification System.

${ }^{\mathrm{d}}$ Silty sand.

${ }^{\mathrm{e}}$ Poorly graded gravel.

${ }^{\mathrm{f}}$ American Association of State Highway and Transportation Officials (AASHTO)

The specific gravity of CSS is lightly less than that of natural soil, as seashells is a calcareous material and also is more porous than natural gravel.

Using the Unified Soil Classification System (USCS), natural soil from subgrade is fine silty sand with $14 \%$ of gravel and no more than $17 \%$ of silt without plasticity (SM). CSS can be considered as gravel with $24 \%$ of fine sand and no more than $3 \%$ of fines particles without plasticity (GP). Using the AASHTO classification, natural soil qualifies as A-2-4 (0) and CSS material as A-1-a (0). Both are coarse grained soils, and the GI value of zero means that they are also good materials for subgrades.

B. Grain size gradation

Fig. 3 shows the grain size distribution of both materials. As was noticed before, both materials are coarse grained soils. The subgrade soil has more fine particles than the CSS material. It can be expected that any mix of the materials will increase the gravel particles, and will move the natural soil from sand to gravel.

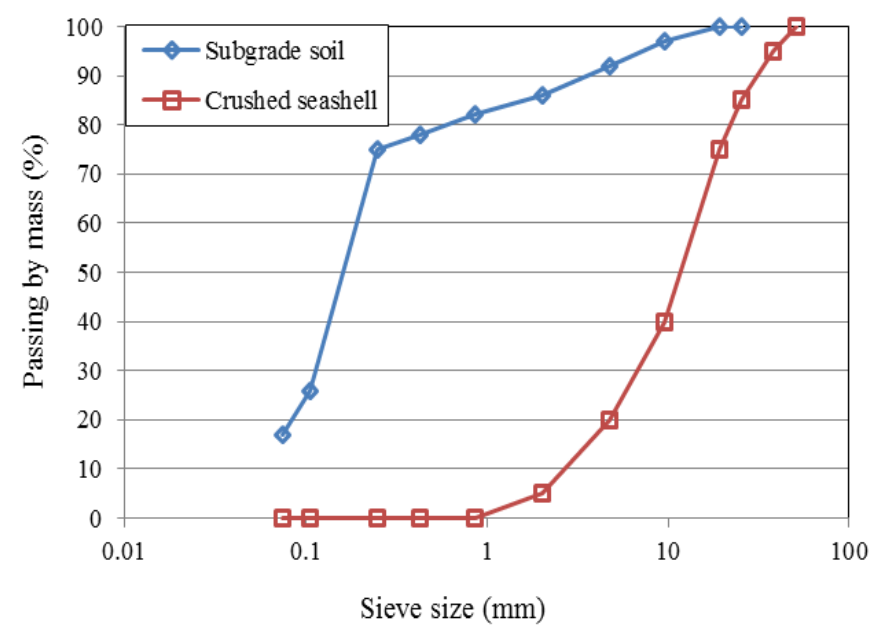

Fig. 3 Grain size distribution of natural subgrade and crushed shell.

$14^{\text {th }}$ LACCEI International Multi-Conference for Engineering, Education, and Technology: "Engineering Innovations for Global Sustainability”, 20-22 July 2016, San José, Costa Rica. 
On the other hand, as they are non-plastic, more compaction effort will be required or even spreading or a lack of stability of the landfill obtained with compacted mixes can be expected. But, on the other hand, less water will be required for compaction as there will not be fine particles in the mix.

\section{Los Angeles abrasion}

The original subgrade soil is sand with Los Angeles abrasion ranging from $12 \%$ to $37 \%$. The CSS abrasion value was $25.2 \%$. This value means that crushed seashell has a high resistance to abrasion and mass loss, thus is similar to natural soil. Based on only this test, it can be concluded that sea shells have resistive properties when they come to be used as a subbase and base course [32,38], with some exposure to passing traffic. But again, the absence of fines may promote spreading or a lack of stability of the base course and some kind of binder would be needed.

\section{Flat and elongated particles}

At a specified test ratio of 3 to 1, it was found that $99 \%$ of particles were flat, $0 \%$ was only elongated and $0 \%$ was flat and elongated. This is a consequence of the shape of the shells, which are laminar, even after crushing. But it also indicates that crushing processes can reduce particles to obtain shapes with enough symmetry to consider them as not being elongated, reducing the amount of elongates particles in the material (Fig. 4).

ASTM specifications [33] requires no more than $20 \%$ of flat and elongated particles by weight for the subbase course, and no more than $15 \%$ for the base course. This material meets both requirements.

\section{E. Mixture gradation}

Fig. 5 presents the grain size distribution of the mixes obtained when CSS is added to natural soil. It can be observed that with increasing CSS content, the soil is less fine. Table II details changes in the soil classification when crushed seashell is added; it varies from a silty sand soil (SM) to a well graded gravel soil $(\mathrm{GW})$.

According to [37], the grain size distribution of mixes should achieve gradations B, C, or D for pavement purposes.

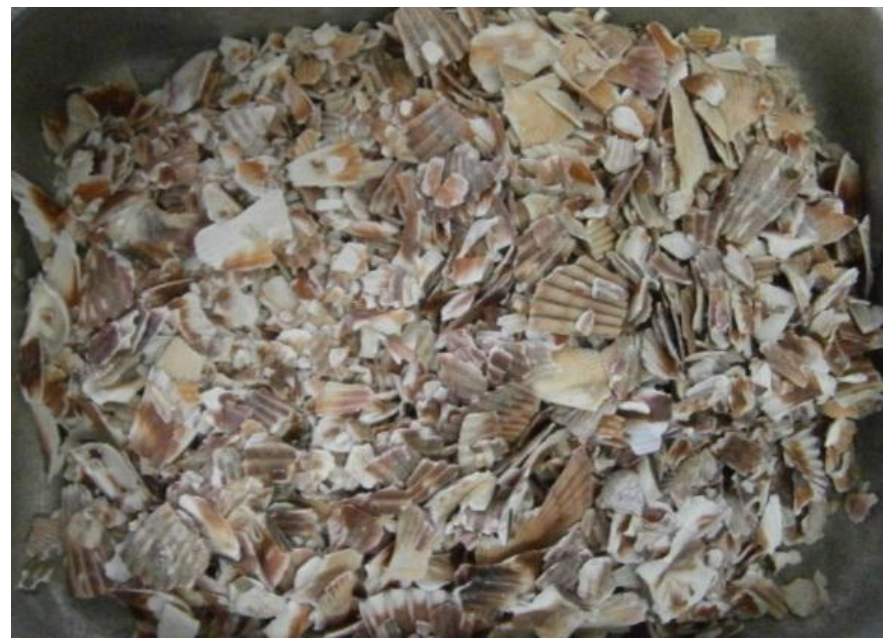

Fig. 4 Flat but not elongated particles of CSS generated after crushing.

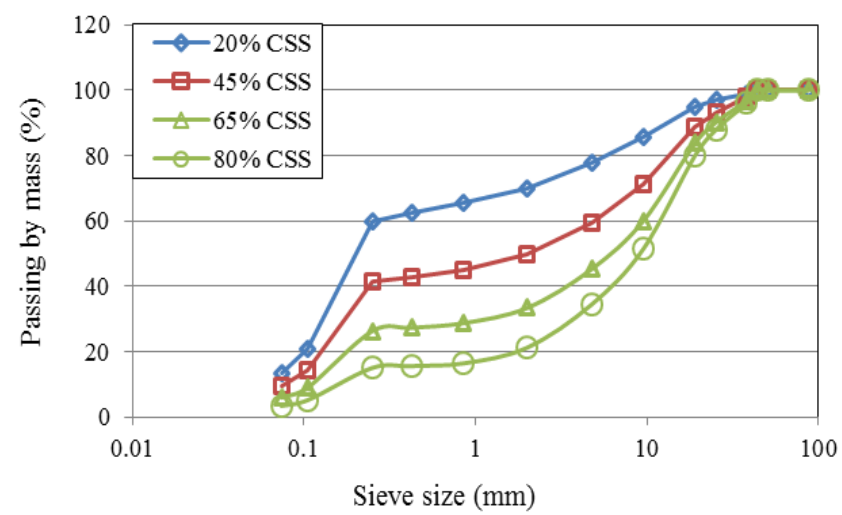

Fig. 5 Grain size distribution of soil and crushed shell combinations.

Some gradation requirements are recommended [37] to ensure good performance on the part of base and subbase courses for roads (gradations A, B, C and D). Natural soil gradation is out of specifications, but almost close to gradation D.

It can be observed that when CSS content is increased in the mix, the grain size distribution of mixes transitions from gradation D to A. This means that CSS acts as gravel, giving to the natural soil the coarse material it does not naturally have.

The absence of plastic fines on natural soil and also in the mixes evaluated limits their utilization to base-course or subbase materials. The use of some other stabilizing material such as clay, lime, cement or asphalt available locally, could permit the material to achieve the requirements needed for a surface course layer. The presence of non-plastic fines contributes to the effective use of those binders.

TABLE II

EFFECT OF CSS ADDITION ON GRAIN SIZE DISTRIBUTION OF NATURAL SOIL

\begin{tabular}{|c|c|c|c|c|c|c|c|}
\hline \multirow{2}{*}{ Sieve } & \multirow{2}{*}{$\begin{array}{c}\text { Opening } \\
(\mathrm{mm})\end{array}$} & \multirow{2}{*}{$\begin{array}{c}\text { Natural } \\
\text { soil }\end{array}$} & \multirow{2}{*}{$\begin{array}{c}\text { Crushed } \\
\text { seashell }\end{array}$} & \multicolumn{5}{|c|}{ CSS Content } \\
\cline { 5 - 8 } & 50.8 & 100 & 100 & 100 & 100 & 100 & 100 \\
\hline $13 / 4$ & 43.75 & 100 & 100 & 100 & 100 & 100 & 100 \\
\hline $1 \frac{1}{2}$ & 38.1 & 100 & 95 & 99 & 97.8 & 96.8 & 96 \\
\hline 1 & 25.4 & 100 & 85 & 97 & 93.3 & 90.3 & 88 \\
\hline $3 / 4$ & 19.1 & 100 & 75 & 95 & 88.8 & 83.8 & 80 \\
\hline $3 / 8$ & 9.53 & 97 & 40 & 85.6 & 71.4 & 60 & 51.4 \\
\hline 4 & 4.76 & 92 & 20 & 77.6 & 59.6 & 45.2 & 34.4 \\
\hline 10 & 2 & 86 & 5 & 69.8 & 49.6 & 33.4 & 21.2 \\
\hline 20 & 0.85 & 82 & 0 & 65.6 & 45.1 & 28.7 & 16.4 \\
\hline 40 & 0.426 & 78 & 0 & 62.4 & 42.9 & 27.3 & 15.6 \\
\hline 60 & 0.25 & 75 & 0 & 60 & 41.3 & 26.3 & 15 \\
\hline 140 & 0.106 & 26 & 0 & 20.8 & 14.3 & 9.1 & 5.2 \\
\hline 200 & 0.074 & 17 & 0 & 13.6 & 9.4 & 6 & 3.4 \\
\hline $\begin{array}{l}\text { USCS } \\
\text { classification }\end{array}$ & SM & GP & SM & SW & GW & GW \\
\hline $\begin{array}{l}\text { AASHTO } \\
\text { classification }\end{array}$ & $\begin{array}{c}\text { A-2-4 } \\
(0)\end{array}$ & $\begin{array}{c}\text { A-1-a } \\
(0)\end{array}$ & $\begin{array}{c}\text { A-2-4 } \\
(0)\end{array}$ & $\begin{array}{c}\text { A-1-b } \\
(0)\end{array}$ & $\begin{array}{c}\text { A-1-a } \\
(0)\end{array}$ & $\begin{array}{c}\text { A-1-a } \\
(0)\end{array}$ \\
\hline
\end{tabular}

SM: Silty fine sand.

SW: Sand well graded.

GP: Gravel poorly graded.
GW: Gravel well graded.

$14^{\text {th }}$ LACCEI International Multi-Conference for Engineering, Education, and Technology: "Engineering Innovations for Global Sustainability”, 20-22 July 2016, San José, Costa Rica. 
On the other hand, as gradation A is for zones above 3000 m.a.s.l. (metres above sea level), it can be considered that the freezing resistance of natural soil can be improved when CSS replacement is increased. It can be also interpreted that an $80 \%$ CSS mix has more voids, and can let water freeze inside the material with little effect on its bearing capacity. Using the classification of mixed soil, it can be confirmed that this goes from silty sand (SM) when it is in the form of original soil, to well graded gravel (GW) when $80 \%$ of CSS is added.

\section{F. Compaction properties}

The moisture and density relations of the original soil and mixes were evaluated. The Modify Proctor Density was evaluated and plotted in Fig. 6; values are detailed in Table III. The results show that CSS increases the maximum dried density of the soil up $45 \%$ replacement. More than $45 \%$ of CSS in natural soil reduces the maximum dry density. In all cases, less water content is required for compaction. The reason for lower optimum moisture content is a reduction in the fines content.

This effect can be explained because natural soil is sand, and the CSS acts as gravel. Small particles of sand act as a matrix and CSS particles as a dispersed phase. Unless the particles of CSS are flat, they are big enough to permit enough mobility between the continuous phases of the sand. The presence of more than $45 \%$ of CSS particles generates more voids, and requires more sand to fill the spaces between the big particles, thereby reducing density.

On the other hand, more CSS particle content in natural soil requires less water content to achieve good compaction (Table III). It can be attributed to the shape and size of the particles. When particles are bigger, a smaller surface in terms of particles is available, and less water in needed to lubricate each particle. So, using CSS in addition to natural soil means that a better density can be obtained using less water with the same compaction energy. This is an important consideration for projects taking place in drier climates where moisture sensitivity is a concern.

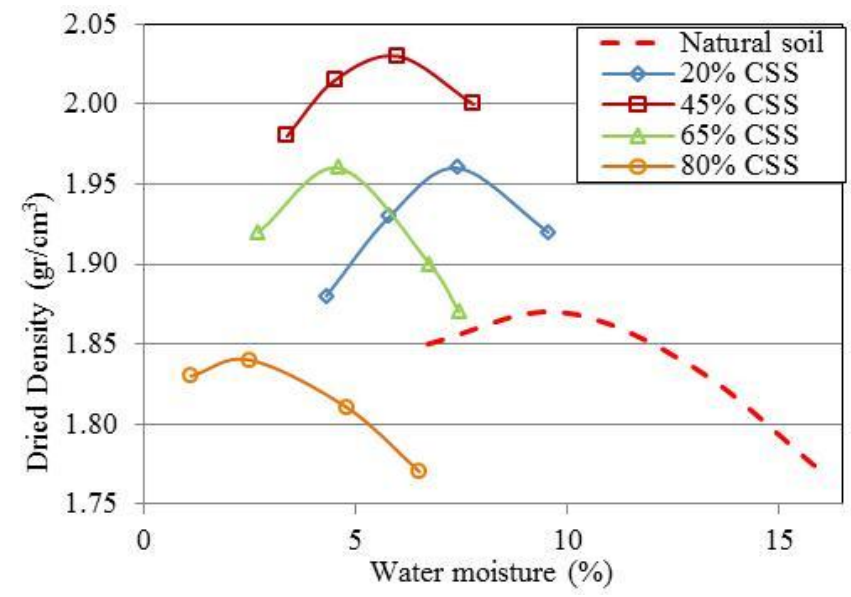

Fig. 6 Effect of soil replacement by CSS on compaction properties.

It can be noted too that, in all cases, optimal water content is less than the natural soil water content (Tables I and III). This can be explained because both materials are coarse grained soils, and the water requirement for the compaction process is very small. It can be interpreted that natural soil meets the water requirements in terms of achieving the maximum dried density during the stabilization process, and no extra water is required. This consideration can be beneficial as no extra water needs to be moved to the work site and the costs of stabilization can be reduced considerably as a result.

TABLE III

COMPACTION PROPERTIES OF MIXES AND NATURAL SOIL

\begin{tabular}{|l|c|c|c|c|c|}
\hline \multirow{2}{*}{ Parameter } & $\begin{array}{c}\text { Natural } \\
\text { soil }\end{array}$ & \multicolumn{4}{|c|}{ CSS addition } \\
\cline { 2 - 6 } & SM & $20 \%$ & $45 \%$ & $65 \%$ & $80 \%$ \\
\hline Optimal water content (\%) & 9.8 & 7.4 & 6.0 & 4.6 & 2.5 \\
\hline Dry Density $\left(\mathrm{g} / \mathrm{cm}^{3}\right)$ & 1.87 & 1.96 & 2.03 & 1.96 & 1.84 \\
\hline
\end{tabular}

The CSS effect on CBR was also evaluated. CBR values were evaluated at $100 \%$ maximum dry density and the optimum water content was determined using the modified Proctor compaction test for each replacement (20\%, 40\%, $60 \%$, and $80 \%$ ) and in a soaked condition. The values of CBR of samples with CSS additional content are plotted in Fig. 7. Natural soil is represented by $0 \%$ replacement.

The CSS addition increases the CBR of natural soil. The specimen with $45 \%$ CSS replacement had the highest CBR of $121 \%$ which was better than the CBR of $51 \%$ for the specimen with $0 \%$ replacement. Because the presence of larger particles of CSS act as gravel, the soil with CSS behaves as a high quality material, more like the standard crushed rock material used as comparison in the CBR test.

However, a tendency to get a maximum CBR for a determined CSS content can be observed. More than $45 \%$ of CSS tends to reduce the CBR value in the mix, but this is still higher than natural soil. It seems that excess of flat particles found in CSS generates more voids in the soil that could not be filled by sand. On the other hand, the lack of fines reduces the stability of particles, and the soil tends to collapse easily during compaction.

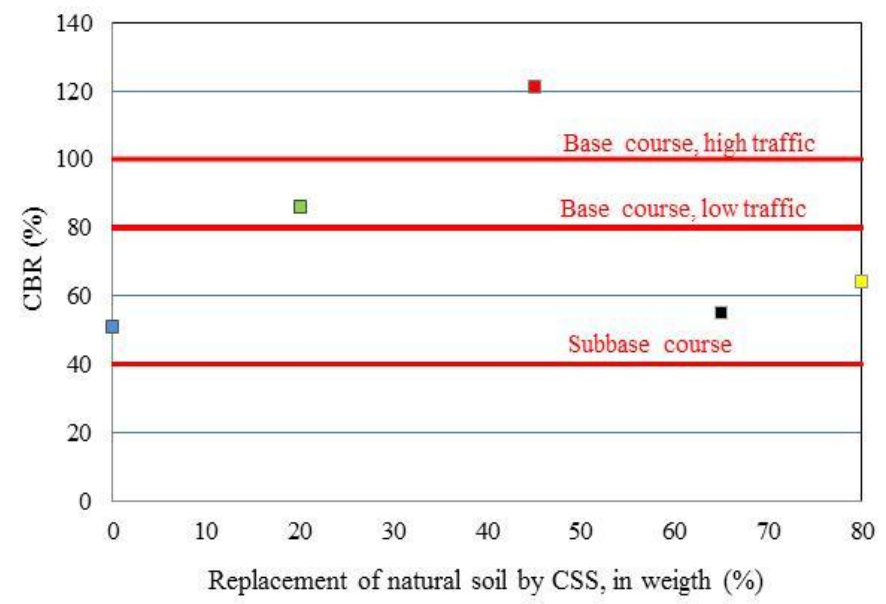

Fig. 7 Effect of CSS replacement on CBR of natural soil.

It is interesting to note that even when the $80 \%$ CSS replacement has less maximum dry unit weight than natural

$14^{\text {th }}$ LACCEI International Multi-Conference for Engineering, Education, and Technology: "Engineering Innovations for Global Sustainability”, 20-22 July 2016, San José, Costa Rica. 
soil (Fig. 6), the CBR value is still higher than that of the control group $(0 \%)$. This can offer the opportunity to include a high proportion of crushed seashells as part of subgrade materials without compromising the quality of the natural soil.

Compared to AASHTO specifications, more than $20 \%$ CSS replacement allows the soil to qualify as a base course. If the CSS replacement goes to $45 \%$, it could meet high load traffic base course requirements. In any case, it is evident that the surface course or the use of some binder material to improve wear and tear is required because of a lack of cohesion in the material.

No expansion was found in all mixes or natural soil. This cannot be attributed to a shortage of either fines or plasticity in the samples.

\section{G. Changes on grain size distribution after compaction}

Compaction tests can change the grain size distribution. The application of high compaction energy may break particles, especially if they are flat. In this case, shells can be reduced in size after application of the compaction effort. So, grain size distribution was evaluated in samples with $65 \%$ of CSS replacement after compaction (Fig. 8).

A significative reduction in larger particles can be observed. Because of the flat shape of the crushed seashell, compaction energy crushes them even more, reducing the size of these grains further. This can explain the significative unexpected reduction on $\mathrm{CBR}$ in respect of the control group $(0 \%)$. Apparently, the presence of the sand in the mix can act as a shock absorber to protect any shell particles from the compaction energy effect. This can also contribute to the reduction of the CBR when more than $45 \%$ CSS replacement is used: seashell particles are broken and reduced in size, limiting its effect on the mix. Even so, a sample with $65 \%$ CSS replacement still has a good bearing capacity.

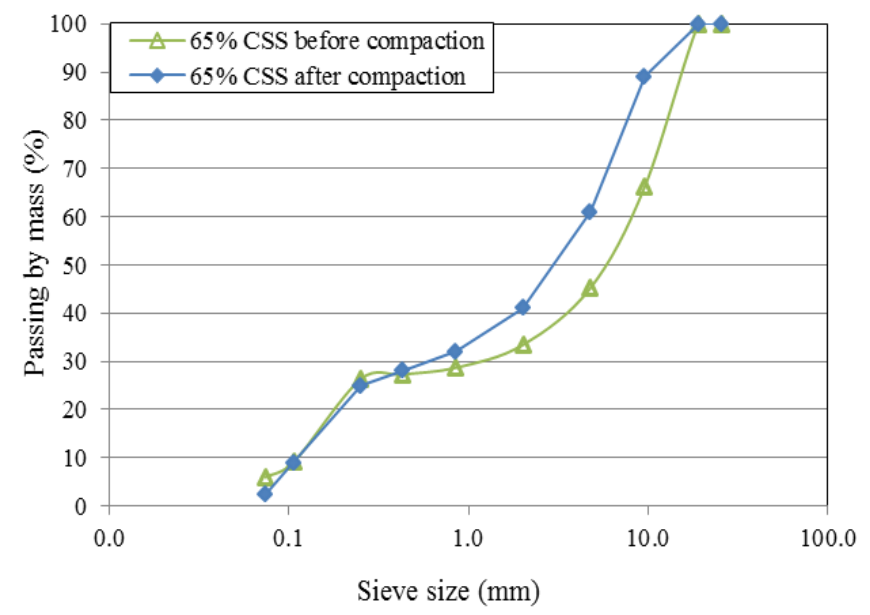

Fig. 8 Grain size distribution of material before and after compaction process.

\section{CONCLUSIONS}

CSS can be considered as a gravel material, with flat but non-elongated particles of $25 \%$ of the Los Angeles loss value. It meets the requirements for it to be used as a sub-base and base coarse.
CSS addition to sandy soil increases the maximum density of sandy soil using less water than the control group with the same compaction energy. The CSS addition increases the CBR of the sandy soil from $51 \%$ to more than $100 \%$.

The CSS addition to sandy soil can be used efficiently as a mechanical stabilization of sandy soil as a way of improving pavement requirements, even for a high load traffic base course.

Lack of cohesion in sandy soil and CSS requires the use of a binder to be used as a surface course in rural roads.

It can be concluded that crushed waste Peruvian Scallop has the potential to perform as a mechanical soil stabilizer or for soil modification. Changes in the physical properties of seashells may be of concern as any variation could have an effect on its mechanical properties. This consideration justifies further research.

\section{REFERENCES}

[1] de Alvarenga, Rodrigo Augusto Freitas, Galindro, B. M., Helpa, C. d. F., and Soares, S. R., "The recycling of oyster shells: an environmental analysis using Life Cycle Assessment," Journal of environmental management, vol. 106, pp. 102-109, 2012.

[2] Ohimain, E. I., Bassey, S., and Bawo, D. D., "Uses of Seas Shells for Civil Construction Works in Coastal Bayelsa State, Nigeria: A Waste Management Perspective," Research Journal of Biological Sciences, vol. 4, no. 9, pp. 1025-1031, 2009.

[3] Richardson, A. E. and Fuller, T., "Sea shells used as partial aggregate replacement in concrete," Structural Survey, vol. 31, no. 5, pp. 347-354, 2013.

[4] Wang, H.-Y., Chen, P.-Y., and Chen, J.-H., "Effect of waste oyster shell resurgent on engineering properties of cement mortar," In 2011 International Conference on Consumer Electronics, Communications and Networks (CECNet), 4941-44.

[5] Wang, H.-Y., Kuo, W.-T., Lin, C.-C., and Po-Yo, C., "Study of the material properties of fly ash added to oyster cement mortar," Construction and Building Materials, vol. 41, pp. 532-537, 2013.

[6] Yang, E.-I., Kim, M.-Y., Park, H.-G., and Yi, S.-T., "Effect of partial replacement of sand with dry oyster shell on the long-term performance of concrete," Construction and Building Materials, vol. 24, no. 5, pp. 758-765, 2010.

[7] Yang, E.-I., Yi, S.-T., and Leem, Y.-M., "Effect of oyster shell substituted for fine aggregate on concrete characteristics: Part I. Fundamental properties," Cement and Concrete Research, vol. 35, no. 11, pp. 2175-2182, 2005.

[8] Yoon, G.-L., Kim, B.-T., Kim, B.-O., and Han, S.-H., "Chemicalmechanical characteristics of crushed oyster-shell," Waste Management, vol. 23, no. 9, pp. 825-834, 2003

[9] Chierighinia, D., Bridib, R., da Rochac, A. A., and Lapad, K. R., Possibilidades do Uso das Conchas de Moluscos. 3rd. International Workshop Advances in Cleaner Production. Sao Paulo, Brazil, 2011.

[10] Safiuddin, M., Jumaat, M. Z., Salam, M., Islam, M., and Hashim, R., "Utilization of solid wastes in construction materials," International Journal of the Physical Sciences, vol. 5, no. 13, pp. 1952-1963, 2010.

[11] Adewuyi, A. P. and Adegoke, T., "Exploratory study of periwinkle shells as coarse aggregates in concrete works," ARPN Journal of Engineering and Applied Sciences, vol. 3, no. 6, pp. 1-5, 2008.

[12] Dahunsi, B., "Properties of periwinkle-granite concrete," Journal of Civil Engineering, vol. 8, pp. 27-36, 2002.

[13] Kuo, W.-T., Wang, H.-Y., Shu, C.-Y., and Su, D.-S., "Engineering properties of controlled low-strength materials containing waste oyster shells," Construction and Building Materials, vol. 46, pp. 128-133, 2013.

[14] Lalitha, G. and Krishna Raju, C., "Experimental Study on Performance of Concrete M30 with Partial Replacement of Coarse Aggregate with Sea Shells and Coconut Shells," Int. Journal of Engineering Research and Applications, vol. 4, no. 8 (version 3), pp. 148-151, 2014.

$14^{\text {th }}$ LACCEI International Multi-Conference for Engineering, Education, and Technology: "Engineering Innovations for 
[15] Nguyen, D. H., Boutouil, M., Sebaibi, N., Leleyter, L., and Baraud, F., "Valorization of seashell by-products in pervious concrete pavers," Construction and Building Materials, vol. 49, pp. 151-160, 2013.

[16] Osarenmwinda, J. O. and Awaro, A. O., "The Potential Use of Periwinkle Shell as Coarse Aggregate for Concrete," AMR, vol. 62-64, pp. 39-43, 2009.

[17] Safi, B., Saidi, M., Daoui, A., Bellal, A., Mechekak, A., and Toumi, K., "The use of seashells as a fine aggregate (by sand substitution) in selfcompacting mortar (SCM)," Construction and Building Materials, vol. 78, pp. 430-438, 2015.

[18] Lee, C. J., "A study on the application of oyster powder as a cementitious material," Master Thesis, National Taiwan Ocean University, 2005.

[19] Namdar, A., Yahaya, F. M., Shan, C. P., and Rajagopal, N. S., "Effect of Seashell Powder on Flexural and Compressive Strength of Cement Mortar in Early Age," AMR, vol. 894, pp. 65-69, 2014.

[20] Wahyuni, A. S., Supriani, F., Elhusna, and Gunawan, A., "The Performance of Concrete with Rice Husk Ash, Sea Shell Ash and Bamboo Fibre Addition," Procedia Engineering, vol. 95, pp. 473-478, 2014.

[21] Arabani, M., Babamohammadi, S., and Azarhoosh, A. R., "Experimental investigation of seashells used as filler in hot mix asphalt," International Journal of Pavement Engineering, vol. 16, no. 6, pp. 502-509, 2014.

[22] Bermudez Corcuera, P. I., Maidana Cuadros, J. C., Aquino Bravo, H., and Palomino Ramos, A. R., Manual de Cultivo Suspendido de Concha de Abanico, Edición Exclusiva. Lima, Perú: Fondepes-AECIPADESPA, 2004

[23] Jayaganesh, K., Yuvaraj, S., Yuvaraj, D., Nithesh, C., and Karthik, G., "Effect of bitumen emulsion and sea shell powder in the unconfined compressive strength of black cotton soil," International Journal of Engineering Research and Applications (IJERA), vol. 2, no. 3, pp. 242245, 2012.

[24] Yamada, M., Taniguchi, K., Okumura, M., and Sano, H., "Deflection properties of pavement constructed on subgrade containing crushed oyster shell," Zairyo, vol. 53, no. 1, pp. 25-28, 2004
[25] Rowland Otoko, G. and Esenwa Ifechukwude, C., "Mechanical stabilization of a deltaic clayey soil using crushed waste periwinkle shells," International Journal of Engineering and Technology Research, vol. 2, no. 5, pp. 1-7, May. 2014.

[26] Baltazar Guerrero, P. M. and Palacios, L. J., "La acuicultura en el Perú: producción, comercialización, exportación y potencialidades," In VII Foro Iberoamericano de Recursos Marinos y Acuícolas, 293-305, 2015.

[27] Poicón Rivas, S., "En Sechura se arrojan 100 mil toneladas al año de residuos de concha de abanico," El Tiempo, 2014.

[28] Limaymanta Sulca, E., "Si no para la contaminación, no renovarán permisos a las procesadoras en Sechura," El Tiempo, 2014.

[29] Wheaton, F., "Review of the properties of Eastern oysters, Crassostrea virginica," Aquacultural Engineering, vol. 37, no. 1, pp. 3-13, 2007.

[30] ASTM D 6913 Standard Test Methods for Particle-Size Distribution (Gradation) of Soils Using Sieve Analysis.

[31] ASTM D 4318 Standard Test Methods for Liquid Limit, Plastic Limit, and Plasticity Index of Soils.

[32] ASTM C 131 Standard Test Method for Resistance to Degradation of Small-Size Coarse Aggregate by Abrasion and Impact in the Los Angeles Machine.

[33] AASHTO T-96 Resistance to Degradation of Small-Size Coarse Aggregate by Abrasion and Impact in the Los Angeles Machine.

[34] ASTM D 4791-10. Standard Test Method for Flat Particles, Elongated Particles, or Flat and Elongated Particles in Coarse Aggregate.

[35] AASHTO T180. Standard Method of Test for Moisture-Density Relations of Soils Using a 4.54-kg (10-lb) Rammer and a 457-mm (18in.) Drop.

[36] ASTM D 1883 Standard Test Method for California Bearing Ratio (CBR) of Laboratory-Compacted Soils.

[37] ASTM D 1241 Standard Specification for Materials for Soil-Aggregate Subbase, Base, and Surface Courses.

[38] Little, D.N., and Nair, S., Recommended Practice for Stabilization of Subgrade Soils and Base Materials, NCHRP Web-Only Document 144, National Cooperative Highway Research Program, Transportation Research Board. Washington, DC. PDF version available: http://onlinepubs.trb.org/onlinepubs/nchrp/nchrp_w144.pdf, 2009.

$14^{\text {th }}$ LACCEI International Multi-Conference for Engineering, Education, and Technology: "Engineering Innovations for 